\title{
Factors associated with suicide risk among nurses and physicians: a cross-section study
}

\author{
Fatores associados ao risco de suicídio entre enfermeiros e médicos: estudo transversal
}

Factores asociados al riesgo de suicidio entre enfermeros y médicos: un estudio transversal

Factores asociados al riesgo de suicid
Fernanda de Oliveira Freire',"1
ORCID: 0000-0002-2729-7719
Samira Reschetti Marcon"
ORCID: 0000-0002-5191-3331
Mariano Martínez Espinosa"
ORCID: 0000-0002-0461-5673
Hugo Gedeon Barros dos Santos ",II"
ORCID: 0000-0001-7713-1314
Moisés Kogien"
ORCID: 0000-0003-4591-6648
Nathalie Vilma Pollo de Lima"
ORCID: 0000-0001-5558-972X
Jesiele Spindler Faria"
ORCID: 0000-0003-0078-1743

'Prefeitura Municipal de São José dos Quatro Marcos. São José dos Quatro Marcos, Mato Grosso, Brazil. "Universidade Federal de Mato Grosso. Cuiabá,

Mato Grosso, Brazil. "' Universidade Federal de Mato Grosso, Hospital Universitário Júlio Müller. Cuiabá, Mato Grosso, Brazil

How to cite this article: Freire FO, Marcon SR, Espinosa MM, Santos HGB, Kogien M, Lima NVP, et al. Factors associated with suicide risk among nurses and physicians: a cross-sectional study. Rev Bras Enferm. 2020;73(Suppl 1):e20200352. doi: http://dx.doi.org/10.1590/0034-7167-2020-0352

Corresponding author: Fernanda de Oliveira Freire E-mail: ferfreire3@hotmail.com

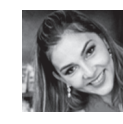

EDITOR IN CHIEF: Antonio José de Almeida Filho ASSOCIATE EDITOR: Ana Fátima Fernandes

\section{ABSTRACT}

Objective: to estimate the prevalence and factors associated with suicide risk among nurses and physicians. Method: a cross-sectional study carried out at a university hospital with 216 health professionals, who answered a socio-demographic-labor questionnaire, the Mini International Neuropsychiatric Interview (MINI) for assessing suicide risk, and the Depression, Anxiety and Stress Scale (DASS 21). The Poisson Regression Model was used for multiple analysis. Results: it was identified that variables such as not having a partner, history of attempted suicide, stress and depression symptoms were statistically associated with suicide risk. The prevalence of lifelong suicide attempts among nurses was $9.41 \%$, and among physicians, $2.29 \%$. Conclusion: the findings of this investigation enable the understanding of suicidal behavior among hospital nurses and physicians, in addition to enabling the development of prevention strategies in order to reduce suicide risk prevalence in this population group. Descriptors: Health Professionals, Nurses; Physicians; Suicide; Associated Factors.

\section{RESUMO}

Objetivo: estimar a prevalência e os fatores associados ao risco de suicídio entre enfermeiros e médicos. Método: estudo transversal, desenvolvido em um hospital universitário com 216 profissionais da saúde, que responderam a um questionário sociodemográfico-laboral; ao Mini International Neuropsychiatric Interview (MINI), para avaliação do risco de suicídio; Escala de Depressão, Ansiedade e Estresse (DASS 21). Utilizou-se para análise múltipla, o Modelo de Regressão de Poisson. Resultados: identificou-se que variáveis, como não ter companheiro, histórico de tentativa de suicídio, sintomas de estresse e depressão se associaram estatisticamente ao risco de suicídio. A prevalência das tentativas de suicídios ao longo da vida entre enfermeiros foi de $9,41 \%$ e médicos de $2,29 \%$. Conclusão: Os achados desta investigação possibilitam a compreensão do comportamento suicida entre os enfermeiros e médicos da área hospitalar, além de viabilizar a elaboração de estratégias de prevenção com intuito de diminuir a prevalência do risco de suicídio nesse grupo populacional. Descritores: Profissionais da Saúde; Enfermeiros; Médicos; Suicídio; Fatores Associados.

\section{RESUMEN}

Objetivo: estimar la prevalencia y los factores asociados al riesgo de suicidio entre enfermeros y médicos. Método: estudio transversal, desarrollado en un hospital universitario con 216 profesionales de la salud, quienes respondieron un cuestionario sociodemográfico-laboral; el Mini International Neuropsychiatric Interview (MINI), para evaluar el riesgo de suicidio; Escala de Depresión, Ansiedad y Estrés (DASS 21). El modelo de regresión de Poisson se utilizó para el análisis múltiple. Resultados: se identificó que variables como no tener pareja, antecedentes de intento de suicidio, síntomas de estrés y depresión se asociaron estadísticamente con el riesgo de suicidio. La prevalencia de intentos de suicidio de por vida entre enfermeras y médicos fue del $9,41 \%$ y del $2,29 \%$. Conclusión: los hallazgos de esta investigación permiten comprender la conducta suicida entre enfermeros y médicos del área hospitalaria, además de posibilitar el desarrollo de estrategias de prevención con el fin de reducir la prevalencia de riesgo suicida en este grupo poblacional.

Descriptores: Profesionales de la Salud; Enfermeros; Médicos; Suicidio; Factores Asociados. 


\section{INTRODUCTION}

Suicide is not a contemporary phenomenon and has existed in society for a long time ${ }^{(1)}$. Currently, it constitutes a serious public health problem causing individual, social and economic losses ${ }^{(2)}$. Considered a multidimensional behavior, it results from a complex interaction between biopsychosocial, genetic, cultural and environmental factors ${ }^{(3-4)}$.

Suicide accounts for nearly 800,000 worldwide deaths per year. These numbers do not include suicide attempts, which tend to occur 10 to 20 times more than the consummated act ${ }^{(1)}$. In general, the global suicide coefficient is 10.6 per 100,000 inhabitants, comprising $1.4 \%$ of all deaths in the world ${ }^{(1)}$. In Brazil, the suicide mortality rate is 6.1 per 100 thousand inhabitants ${ }^{(5)}$, an index considered low because it is a large and populous country; however, it remains among the ten countries with the highest absolute numbers of suicides ${ }^{(1)}$.

Considering the magnitude of the phenomenon reaffirmed in world statistics, the Brazilian National Policy for the Prevention of Self-mutilation and Suicide (PNPAS - Política Nacional de Prevenção da Automutilaçãoe do Suicídio) was instituted by Law 13,819/2019, aiming to intervene more effectively in its control through compulsory and confidential notification by health establishments, security, schools and guardianship of cases of attempted suicide and self-harm ${ }^{(6)}$.

Although the current legislation covers the general population, some groups in specific circumstances are more exposed to suicide risk, including indigenous people, elderly individuals and young people aged 15 to 29 years ${ }^{(1,3)}$. As for the different categories of work, health professionals when compared to the general population have higher suicide rates ${ }^{(7-9)}$. A North American study carried out between 2005 and 2016 identified suicide rates among nurses and physicians of 18.51 and 40.72 per 100 thousand inhabitants, respectively ${ }^{(10)}$. Another study carried out in 18 Peruvian hospitals found a $19.6 \%$ proportion of suicide risk among physicians ${ }^{(11)}$. Considering these findings, it is emphasized that nurses and physicians have been considered health professionals belonging to groups at risk for suicide ${ }^{(10,12)}$.

In addition to the factors associated with suicide widely described in the general population, some may be due to the function performed and the workplace of health professionals $s^{(9,13)}$. Work in hospital involves several situations that require quick and proficient behaviors, such as dealing with life and death management, with physical, emotional pain and suffering experienced jointly with patients and their families. Such a situation can make the environment stressful ${ }^{(14)}$, predisposing them to mental illnesses, such as stress, anxiety, depression, improper use of psychoactive substances, among others, with the aggravating difficulty that professionals have in seeking specialized hel $p^{(9-10,15)}$. Easy access to various mechanisms used for the suicidal act and the knowledge of how to handle them are also factors that increase the risks to which they may be exposed ${ }^{(9,15-16)}$.

In Brazil, a literature review aimed at analyzing suicide among physicians and medical students pointed out that the main causes of the event in this population were high incidence of psychiatric disorders, such as depression and substance abuse, in addition to psychological distress related to profession experiences, such as long working hours, sleep deprivation, problems with patients, unhealthy environments, financial difficulties and information overload ${ }^{(17)}$.
In Canada, another review investigating suicide risk among nurses and related factors reaffirms the association between work settings and high rates of stress, distress and psychiatric problems. The study points to the need to explore work contexts more consistently in the literature, without losing sight of personal factors, especially associating them with suicide risk ${ }^{(16)}$.

Studies of risk assessment and associated factors have been carried out in different population groups, such as neurological and psychiatric patients ${ }^{(18)}$, outpatients in general ${ }^{(19)}$, prison inmates ${ }^{(20)}$, adolescents ${ }^{(21)}$, university students ${ }^{(22)}$ and patients with chronic diseases ${ }^{(23)}$. Suicide risk among health professionals has been little explored ${ }^{(10,14,16,24)}$. Among the existing studies, four international studies were developed in Peru, Mexico, and Spain ${ }^{(11,25-27)}$ and they showed an increased risk of suicide in this population. In Brazil, to date, there are no studies that specifically assess suicide risk factors among medical professionals and nurses; however, there is an investigation of variables such as quality of life, presence of depressive symptoms, anxiety, occupational stress, Burnout Syndrome, suicidal ideation with some associated factors ${ }^{(14)}$. In this regard, the complexity and fragility in the discussion of the topic is shown precisely between categories that are supposed to work on prevention.

\section{OBJECTIVE}

To estimate the prevalence and factors associated with suicide risk among nurses and physicians.

\section{METHODS}

\section{Ethical aspects}

The research protocol was approved by the Research Ethics Committee with Human Beings of Hospital Universitário Júlio Müller in June 2018 and observed all recommendations of Resolution 466/12, of the Brazilian National Health Council (Conselho Nacional de Saúde). All necessary procedures were maintained to ensure free participation, confidentiality, anonymity, security and privacy. All professionals consented to participate in the study by signing the Informed Consent Form (ICF), were previously advised by the research assistants about the research objectives and who could withdraw from participating at any time. The risks and losses caused were minimal. However, as the questions were related to suicidal behavior, professionals responded individually and with privacy, research assistants waited in the clinic corridor or another time was arranged to collect the instruments, in order to minimize possible discomfort. With the purpose of not identifying the participants and guaranteeing anonymity, the data obtained in the study were forwarded to the hospital's board for the formulation of interventions aimed at health professionals.

\section{Design, place of study, and period}

An associative cross-sectional study was carried out with professional nurses and physicians from a university hospital located in the city of Cuiabá, in the state of Mato Grosso, Brazil, between July and September 2018. It is a federal institution, public and destined exclusively to attend patients of the Brazilian Health 
System (SUS - Sistema Único de Saúde). On November 12, 2013, it partnered up with the Brazilian Hospital Services Company (EBSERH - Empresa Brasileira de Serviços Hospitalares) and has other employees with varied employment relationships, as governed by the Consolidation of Labor Laws (The Consolidation of Labor Laws (Consolidação das Leis do Trabalho CLT) is the decree which governs labor relations in Brazil), Unified Legal Regime (RJU Regimento Jurídico Único) and the assigned professionals from Municipal Health Department (MHD), State Health Department (SHD), and Ministry of Health (MoH). At the time of the study, there were 116 beds agreed to assist various medical-surgical specialties, including adult/neonatal intensive care, obstetrics and pediatrics, being the reference health institution for 14 municipalities in the region. The STROBE (Strengthening the Reporting of Observational Studies in Epidemiology) guidelines ${ }^{(28)}$ were used to ensure the quality of the dissemination of this study.

\section{Population/sample and eligibility criteria}

It was a census study, in which the eligible population was 232 professional nurses and physicians, 88 nurses and 144 physicians. All professional nurses and physicians who worked at the institution at the time of data collection have been included, regardless of the type of employment contract and aged over 18 years. Those who were on vacation, sick leave or leave have been excluded. Of these 232 , two refused to participate in the study, five were not found in the sector or were busy, eight returned incomplete questionnaires (missing data) and were excluded and one was part of the pilot test. Thus, the final sample had 216 professionals ( 85 nurses and 131 physicians), representing $93.10 \%$ of the population.

\section{Study protocol}

Data were collected by research assistants consisting of a master's student in nursing and three undergraduate nursing students, inserted in the Scientific Initiation Program (PIBIC) of a Public University, who were previously trained in order to standardize the collection. A chunk containing three self-applicable instruments was made available to respondents in their workplace, after an invitation and clarification about the research, and later they were collected in a sealed ballot box. Scale reliability tests were performed specifically for the population of this study, using Cronbach's alpha coefficient and Kuder-Richardson (KR-20). Thus, the following instruments were used:

- A questionnaire to assess sociodemographic, labor and history of suicidal behaviors of the professional (previous suicide attempt and method used), family and friends (suicide attempt and suicide), designed exclusively for this study;

- A version adapted for self-applied form of module $C$ of version 5.0 of the Mini International Neuropsychiatric Interview (MINI) $(K R-20=.574)$ was used to stratify suicide risk. This version of the instrument was translated into Brazilian Portuguese ${ }^{(29)}$, and its validity and applicability were subsequently assessed with good psychometric indicators ${ }^{(30)}$. It is worth noting that this instrument was adapted for self-application so that participants had more privacy in responding to suicidal behavior, since the theme is permeated by stigma and prejudice.
Suicide risk was obtained considering the questions that assess suicidal behavior in the last 30 days and, also, throughout life. The instrument allows a maximum total score of 33 points, with dichotomous responses (yes and no). Each "yes" answer receives a specific score according to the severity of the suicidal behavior presented. Suicide risk can be stratified into low (1-5 points), moderate (6-9 points) and high ( $\geq 10$ points) risk. For the purposes of analysis, in this study, the value zero was considered to be without risk for suicide (absence), and values from 1 to 33 points were classified as at risk of suicide;

- Abbreviated version of the Depression, Anxiety and Stress Scale (DASS-21) ( $a=.935)$ used to assess depressive, anxious and stress symptoms. This instrument was adapted for use in Brazil $^{(31)}$ and validated for use in an adult population ${ }^{(32)}$ presenting adequate reliability and validity for the sample. It consists of three subscales, being depression ( $\alpha=.865)$, anxiety $(\alpha=.853)$, and stress $(\alpha=.893)$. Four-point Likert-type answers were used to assess how often and intensely the respondent perceives signs and symptoms of the mental illness outcomes mentioned above. The DASS-21 provides three scores ranging from " 0 " to " 21 " obtained from the sum of each of the seven questions that make up each domain of the instrument, with the score for each subscale subsequently multiplied by two, according to the original authors recommendations, generating a final score ranging from 0 to 42 points $^{(33)}$. From this final score, the subjects were classified according to the presence of symptoms, being categorized as normal, mild, moderate, severe or extremely severe ${ }^{(31)}$. For the purposes of analysis, the mild, moderate, severe and extremely severe groups were recoded into a single category called "presence of symptoms" and the normal group recoded to represent the "absence of symptoms" of depression, anxiety or stress.

\section{Statistical analysis of data}

Office Excel for Windows', version 2013, was used to construct the database. The data obtained were encoded and double entered in spreadsheets different from that program and later compared for inconsistencies by Epi Info, version 3.5.4. Statistical Package for the Social Sciences (SPSS), version 20, was used to perform statistical calculations.

Each instrument was analyzed using elements of descriptive statistics recommended by their respective authors; subsequently, the results obtained were assessed in an associative manner, verifying which sociodemographic-labor and mental health elements were significantly associated with suicide risk (dependent variable). Pearson's chi-square test and Fisher's exact test (when relevant) were applied in the bivariate analysis, with a significance level less than or equal to 0.05 ( $p \leq 0.05)$ and a $95 \%$ confidence interval. To identify potential associated factors, a Poisson multiple regression model was used, with Robust variance to obtain adjusted prevalence $\operatorname{ratios}^{(34)}$.

Independent variables were included, which in the bivariate analysis had a $p$ value less than or equal to $0.20(p \leq 0.20)$ as well as the interactions between the independent variables, i.e., the simultaneous interaction of two independent variables affecting the dependent variable. In the final model, the variables that reached $p$ value less than or equal to $0.05(p \leq 0.05)$. 


\section{RESULTS}

In relation to the main sociodemographic and labor issues, the population studied was characterized by a predominance of females (68.06\%), aged 39 to 59 years (57.87\%), Catholics (59.26\%), orientation heterosexual sex (95.83\%), marital status with a partner (73.61\%) and family income above 20 minimum wages (class A) $(50.93 \%)$. Of these, $60.65 \%$ were physicians, $99.07 \%$ had a graduate course, $91.20 \%$ worked in health care sectors and $69.44 \%$ had worked in hospitals less than or equal to five years. As for weekly workload, $54.17 \%$ reported working 24 hours or less; $78.70 \%$ worked only on a day shift and $59.26 \%$ had two or more jobs.

As for the suicidal behavior of health professionals, 5.09\% reported having attempted suicide throughout their lives, suicide attempt occurrence throughout life among nurses was $9.41 \%$, and, among physicians, $2.29 \%$. Prevalence of a history of suicide attempt and suicide cases among family members was $23.61 \%$ and $15.28 \%$, respectively. Concerning friends' suicide attempts, there was a percentage of $43.52 \%$ and for suicide, $35.65 \%$.

Table 1 - Prevalence of current suicide risk (last 30 days) among health professionals of the University Hospital (N=216), Cuiabá, Mato Grosso, Brazil, 2018

\begin{tabular}{lccc}
\hline Variable & $\mathbf{n}$ & $\%$ & $* \mathbf{9 5} \% \mathbf{C l}$ \\
\hline $\begin{array}{l}\text { Current suicide risk } \\
\text { At risk }\end{array}$ & 34 & 15.74 & $(11.15 ; 21.29)$ \\
$\quad$ No risk & 182 & 84.26 & $(78.70 ; 88.85)$ \\
Total & 216 & 100 & - \\
\hline Note: ${ }^{* 95 \% ~ C l-C o n f i d e n c e ~ i n t e r v a l ~}$ & &
\end{tabular}

Concerning depressive symptoms, anxiety and stress among nurses (85), prevalence of $27.05 \%, 29.45 \%, 28.23 \%$ were observed, respectively. Among physicians (131), there was a prevalence of $11.45 \%, 14.50 \%$ and $16.03 \%$ for depressive, anxious and stress symptoms. When analyzed together, the professionals presented $17.59 \%$ for depressive symptoms, $20,37 \%$ anxiety symptoms and $20.83 \%$ stress.

Table 1 shows that, of the 216 participants, $15.74 \%$ had a risk of suicide in the last 30 days.

Table 2 shows the associations of variables, sociodemographic, economic and labor of health professionals with suicide risk. It is evident that suicide risk obtained a statistically significant difference with sexual orientation $(p=0.006)$. The highest proportion was among homosexuals (55.55\%), when compared to heterosexuals (14.01\%), and marital status without a partner $(p=0.003)$, with the highest proportion in this category (28.07\%). Suicide risk among nurses was $21.18 \%$ and among physicians, $12.21 \%$; however, in this variable, as well as in others, no statistically significant differences were found.

Although not shown in Table 2, 12.94\% of nurses had a low risk of suicide and $8.24 \%$ a high risk. Among physicians, $5.34 \%$ of professionals with low risk were found, $3.85 \%$ moderate and $3.05 \%$ high risk.

Table 3 shows a statistically significant difference between suicide risk and health professionals with a history of previous suicide attempts $(p<0.001)$.

Table 4 shows a significant association between suicide risk and self-reported depression, anxiety, and stress symptoms, all with highly significant values $(p<0.001)$.

In the multiple regression model, the following variables were tested: sexual orientation $(p=0.006)$; marital status $(p=0.004)$; professional category $(p=0.077)$; weekly workload ( $p=0.098)$; work shift $(p=0.086)$; previous suicide attempt; depression, anxiety, and stress symptoms, with values of $(p<0.001)$. The variables marital status (without a partner) $(\mathrm{p}=0.043)$, previous suicide attempt $(p<0.001)$, stress $(p=0.027)$, depression $(p=0.001)$, and anxiety $(p=0.082)$ symptoms remained in the final model (Table 5).

Table 2 - Association between demographic, socioeconomic and work variables of health professionals at a University Hospital and suicide risk ( $\mathrm{N}=216$ ), Cuiabá, Mato Grosso, Brazil, 2018

\begin{tabular}{|c|c|c|c|c|c|c|c|}
\hline \multirow[b]{2}{*}{ Variable } & \multicolumn{4}{|c|}{ Suicide Risk } & \multirow[b]{2}{*}{$* \mathrm{PR}_{\mathrm{b}}$} & \multirow[b]{2}{*}{$* * 95 \% \mathrm{Cl}$} & \multirow[b]{2}{*}{$p$ value } \\
\hline & $\mathbf{n}$ & (\%) & $\mathbf{n}$ & (\%) & & & \\
\hline \multicolumn{8}{|l|}{ Age } \\
\hline$\leq 39$ years old & 23 & $(18.40)$ & 102 & $(81.60)$ & 1.52 & $(0.78 ; 2.96)$ & 0.208 \\
\hline$\geq 40$ to 59 years old & 11 & (12.08) & 80 & (87.91) & 1.00 & - & - \\
\hline \multicolumn{8}{|l|}{ Sex } \\
\hline Male & 11 & (15.94) & 58 & (84.05) & 1.02 & $(0.53 ; 1.97)$ & 0.956 \\
\hline Female & 23 & (15.64) & 124 & (84.35) & 1.00 & - & - \\
\hline \multicolumn{8}{|l|}{ Sexual orientation } \\
\hline Homosexual & 5 & (55.55) & 4 & (44.44) & 3.97 & $(2.02 ; 7.79)$ & $0.006^{* * *} \mathrm{EF}$ \\
\hline Heterosexual & 29 & (14.01) & 178 & (85.99) & 1.00 & - & - \\
\hline \multicolumn{8}{|l|}{ Marital status } \\
\hline Without a partner & 16 & $(28.07)$ & 41 & (71.93) & 2.48 & $(1.36 ; 4.53)$ & 0.003 \\
\hline With a partner & 18 & (11.32) & 141 & (88.68) & 1.00 & - & - \\
\hline \multicolumn{8}{|c|}{ ****Family income (minimum wage) } \\
\hline$A$ & 12 & $(10.91)$ & 98 & (89.09) & 0.60 & $(0.24 ; 1.48)$ & 0.367 \\
\hline B & 16 & (21.92) & 57 & (78.08) & 1.21 & $(0.52 ; 2.80)$ & 0.661 \\
\hline $\mathrm{C}$ & 6 & (18.18) & 27 & $(81.82)$ & 1.00 & - & - \\
\hline \multicolumn{8}{|l|}{ Professional category } \\
\hline Nurse & 18 & $(21.18)$ & 67 & $(78.82)$ & 1.73 & $(0.94 ; 3.21)$ & 0.077 \\
\hline Physician & 16 & $(12.21)$ & 115 & (87.79) & 1.00 & - & - \\
\hline \multicolumn{8}{|l|}{ Assistance sector } \\
\hline Yes & 30 & (15.23) & 167 & (84.77) & 0.72 & $(0.29 ; 1.84)$ & 0.511 \\
\hline No & 4 & $(21.05)$ & 15 & (78.95) & 1.00 & - & \\
\hline
\end{tabular}




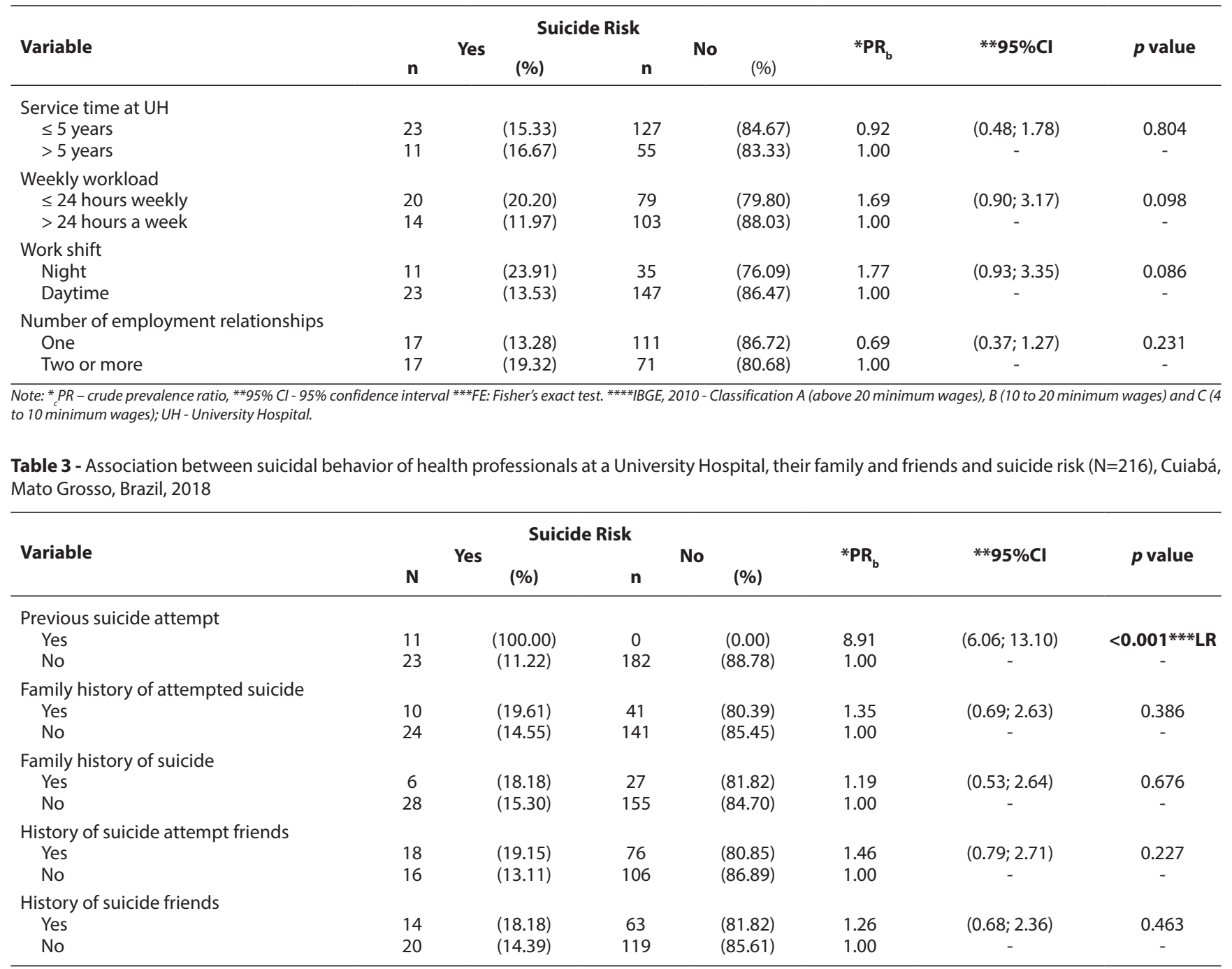

Note: * ${ }_{C} P R$ - crude prevalence ratio; ${ }^{* *} 95 \% \mathrm{Cl}-95 \%$ confidence interval; ${ }^{* * *} \mathrm{LR}$ - likelihood ratio.

Table 4 - Prevalence and association of depressive, anxious and stress symptoms among health professionals at a University Hospital (N=216), Cuiabá, Mato Grosso, Brazil, 2018

\begin{tabular}{|c|c|c|c|c|c|c|c|}
\hline \multirow[b]{2}{*}{ Variable } & \multicolumn{4}{|c|}{ Suicide Risk } & \multirow[b]{2}{*}{ **PR } & \multirow[b]{2}{*}{$95 \% \mathrm{Cl}$} & \multirow[b]{2}{*}{$p$ value } \\
\hline & $\mathbf{n}$ & $\%$ & n & $\%$ & & & \\
\hline \multicolumn{8}{|c|}{ Depression symptoms } \\
\hline Yes & 16 & $(53.33)$ & 14 & $(46.67)$ & 5.51 & $(3.17 ; 9.57)$ & $<0.001 * E F$ \\
\hline No & 18 & $(9.68)$ & 168 & $(90.32)$ & 1.00 & - & - \\
\hline \multicolumn{8}{|c|}{ Anxiety symptoms } \\
\hline Yes & 11 & $(37.93)$ & 18 & $(62.07)$ & 3.08 & $(1.69 ; 5.63)$ & $0.001^{*} \mathrm{EF}$ \\
\hline No & 23 & $(12.30)$ & 164 & $(87.70)$ & 1.00 & - & - \\
\hline \multicolumn{8}{|c|}{ Stress symptoms } \\
\hline Yes & 15 & $(55.56)$ & 12 & $(44.44)$ & 5.53 & $(3.21 ; 9.52)$ & $<0.001 * E F$ \\
\hline No & 19 & $(10.05)$ & 170 & $(89.95)$ & 1.00 & - & - \\
\hline
\end{tabular}

Note: *EF - significant at the level of $5 \%$ by Fisher's exact test, significant at the level of $5 \%$ by chi-square test; ** PR: crude prevalence ratio; *** $95 \% \mathrm{Cl}$ - $95 \%$ interval of confidence.

Table 5 - Factors associated with suicide risk. Multiple regression analysis ( $\mathrm{N}=216)$, Cuiabá, Mato Grosso, Brazil, 2018

\begin{tabular}{llc}
\hline Variable & *PR & **95\% Cl \\
\hline Marital status (without partner) & 1.77 & $(1.02 ; 3.09)$ \\
Previous suicide attempt & 5.20 & $(2.49 ; 10.88)$ \\
Stress & 2.71 & $(1.12 ; 6.55)$ \\
Depression & 3.82 & $(1.70 ; 8.55)$ \\
Anxiety*** & 0.38 & $(0.13 ; 1.13)$
\end{tabular}

Note: * PR-adjusted prevalence ratio; ${ }^{* *} 95 \% \mathrm{Cl}$ - 95\% confidence interval; ${ }^{* * *}$ the anxiety variable, although not statistically significant, remained in the model as an adjustment variable. Statistically significant $p$ values are in bold. 


\section{DISCUSSION}

This study intended to fill a gap in the scientific literature on factors associated with suicide risk among hospital nurses and physicians. It is important to point out that, in Brazil, investigations with this object and study population have not been identified so far. Furthermore, internationally, most of the research carried out with medical professionals and nurses was carried out in northern and/or highly industrialized countries; whose results may not be portrayed in the same way among workers in developing countries who have different working conditions and are affected differently by the effects of globalization and industrialization, as is the case in Brazil ${ }^{(35)}$.

Suicide risk obtained in the present study was $15.74 \%$, similar to that evidenced in a multicenter study carried out with physicians from 18 hospitals in Peru, which showed a prevalence of $19.6 \%{ }^{(11)}$; however, it is much higher than the proportions obtained in three other studies carried out with nurses, university nursing students and resident physicians, in Spain and Mexico $(6.20 \%, 6.40 \%$ and $7.41 \%$, respectively) ${ }^{(25-27)}$. The differences between the prevalence obtained can be related to the different methodological designs, instruments used, as well as to the specific characteristics of certain regions and population groups.

With regard to the associated factors, the final model of analysis demonstrated that not having a partner was a statistically significant factor for suicide risk. Other studies ${ }^{(3,36-37)}$ supported this information by presenting absence of a partner as an important predictor for the risk of self-harm. This is probably because individuals who do not live with a partner, regardless of marital status, seem to be more prone to loneliness, predisposing to depression, anxiety and, consequently, to suicide risk ${ }^{(38-39)}$. Thus, having a marital relationship seems to minimize this risk insofar as the affective interpersonal bonds help in coping with stressful events in the life of an individual without the same resorting to suicide $^{(3,37)}$. A possible explanation for this condition of lack of a partner in this specific group may be an intense professional routine in which it is very common for workers to have several employment relationships; therefore, they put loving relationships in second place, weakening the relationships they may have, reflecting on a probable lonely experience ${ }^{(40-41)}$.

In this study, although the association between suicide risk and previous attempts has been evidenced, it was not possible to illustrate the results of other surveys for the comparison with these health professionals due to the scientific gap on assessment between these variables in this specific population. In addition to a history of suicide attempts, mental illness is also another important factor associated with suicide risk.

History of suicide attempts has been pointed out by researchers and experts as one of the most important predictors of complete suicide ${ }^{(42)}$. Evidence indicates that suicide attempts tend to be recurrent and an individual who has previously attempted suicide is five to six times more likely to try again at a next opportunity when compared to someone who has never attempted suicide ${ }^{(43)}$. Concerning risk of suicide, studies carried out with neuropsychiatric patients demonstrated an association with statistical significance between previous attempts and suicide risk (both with $p<0.001)^{(44-45)}$. The circumstance is more complex between physicians and nurses, as they are work categories that have easy access to mechanisms that can provide constant suicide attempts, such as handling medications and toxic substances and sharp objects, in addition to an adequate knowledge of human anatomy favoring occurrence of self-injuries in lethal anatomical sites ${ }^{(3,10)}$.

Concerning mental distress, people who live with depressive symptoms present sadness, apathy or anhedonia, feeling of guilt or low self-esteem, altered sleep and/or appetite pattern, feeling tired and lack of concentration. Such conditions cause substantial damage to the ability of individuals to perform work activities and successfully cope with everyday situations ${ }^{(1,3)}$; this variable also showed significance in the final mode.

Research shows that the prevalence of depressive symptoms among nurses and physicians is higher when compared to the general population ${ }^{(15,25,46)}$. Factors such as sick workplace, loneliness, family and interpersonal conflicts between workers, occupational stress, lack of professional autonomy, hierarchical relationships between professionals and managers, insecurity in developing activities, night shifts, family income and work overload can significantly influence the occurrence of depressive symptoms among health professionals, especially nurses ${ }^{(14)}$.

Another aspect refers that the difficulties in admitting or recognizing mental problems may be related to the way that such content has been arranged in the academy, without the discussions about interpersonal relationships and self-knowledge being valued. Moreover, there is prejudice, shame and fear of being vulnerable to such situations, opting for self-diagnosis and treatment, making it difficult or postponing the search for help from an expert ${ }^{(47)}$.

This scenario is worrying, since the existence of depressive symptoms can increase suicide risk by up to six times ${ }^{(19)}$. Among mental disorders, severe depressive conditions are the most prevalent among individuals who died by suicide ${ }^{(1,3,36)}$. The findings of the present study demonstrated that suicide risk was more prevalent among individuals with self-reported depressive symptoms, in

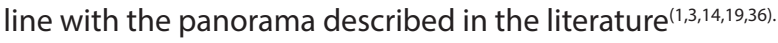

Another element present and with a significant association with suicide risk was stress. This constitutes a condition with potential for chronicity and recurrence that, when excessive and related to workplace, generates a deleterious, unpleasant and negative experience that can affect the workers' physical, mental health and quality of life.

Hospital nurses and physicians experience various stressful situations in their daily work, resulting from the continuous exposure to stressors at work such as scarce dimensioning of material, favoring overload in activities, lack of investment in training/continuing education, feeling of less professional worth, constant contact with death, among others ${ }^{(8,48)}$. These factors contribute to the onset of illnesses or psychological distress, such as depressive disorders and the risk of suicidal behavior ${ }^{(49)}$. Despite the importance of this variable, few studies have investigated the relationship between risk of suicide and stress and, specifically, job stress, especially among nursing professionals ${ }^{(10)}$, which justifies further studies investigating such variables. The demand associated with these two professional categories also deserves attention, since physicians are often responsible for the lives of hospitalized patients and nurses are committed to care in health recovery. These professionals are commonly put the blame on if there is any adversity in the health-disease process, which can exacerbate the stress of their work routines ${ }^{(50)}$. 


\section{Study limitations}

Some limitations need to be highlighted in the present study, such as the impossibility of establishing causal relationships due to the methodological design used and the possibility of underestimating the data due to omission of true information. The topic of suicide is treated as a taboo and not addressed openly in health institutions and services because it is still stigmatized in these spaces and in society in general. In order to minimize this limitation, it was decided to work with self-applicable instruments that were deposited in ballot boxes, guaranteeing participant anonymity.

Difficulty comparing the findings with studies that have assessed suicide risk in this specific population has figured prominently. Concerning the fact that the topic is scarce in the literature, although it is a limitation, it can also be considered a potentiality in that it generates fundamental information to fill this scientific gap and enable interventions directed at this population in hospitals. New studies should be developed on the theme, mainly longitudinal studies that allow establishing a causal relationship and also qualitative studies, aiming at an in-depth analysis on the aspects of life and mental health of professionals.

\section{Contributions to nursing and health}

Suicide risk among health professionals, especially nurses and physicians, is a real and current phenomenon that has gained increasing prominence in the scientific literature, in the media and in the workplace. Such fact occurs, above all, due to its increasingly frequent character and the serious and serious implications and impacts it brings to workers, their family and the community. It is believed that the findings will enable a better understanding of suicidal behavior among hospital health professionals in Brazil, in addition to enabling the development of prevention strategies in order to reduce suicide risk prevalence in this population group. Moreover, since it is a complex, multidetermined problem, interwoven in labor relations and which commonly permeates the "unspoken" terrain in institutions, as it is still considered taboo, it is expected that this study will contribute in some way to foster open discussion and dialogue on workers' suicidal behavior.

\section{CONCLUSION}

The results indicated that the absence of a partner, a history of suicide attempts and variables related to the deterioration of psychic conditions were factors associated with increased prevalence of suicide risk among hospital nurses and physicians. New research needs to be developed, with more robust methodologies that contribute to increase scientific production on suicide risk among nursing professionals and physicians and assist in constructing a solid scientific evidence regarding the identification of risk and predictive factors in this population, especially in Brazil.

\section{REFERENCES}

1. World Health Organization. Depression and other common mental disorders: global health estimates [Internet]. Geneva: World Health Organization; 2017 [cited 2019 May 24]. Available from: http://apps.who.int/iris/bitstream/handle/10665/254610/WHO-MSD-MER-2017.2eng.pdf?sequence $=1$

2. Ferreira Jr A. O comportamento suicida no Brasil e no mundo. Rev Bras Psico [Internet]. 2015 [cited 2018 Dec 05];2(1):15-28. Available from: http://www.mundiblue.com/consultoria/wp-content/uploads/2016/09/O-comportamento-suicida-no-Brasil-e-no-mundo.pdf

3. Botega NJ. Crise Suicida. Porto Alegre: Artmed; 2015.

4. Turecki G, Brent DA. Suicide and suicidal behaviour. Lancet. 2016;387(10024):1227-39. doi: 10.1016/S0140-6736(15)00234-2

5. Ministério da Saúde (BR). Datasus. Óbitos por causas externas - Brasil. Grande grupo CID10: X60-X84. Óbitos por residência segundo sexo, período: 2018 [Internet]. 2018 [cited 2019 May 24]. Available from: http://tabnet.datasus.gov.br/cgi/tabcgi.exe?sim/cnv/ext10uf.def

6. Ministério da Saúde (BR). Lei n 13.819, de 26 de abril de 2019. Institui a Política Nacional de Prevenção da Automutilação e do Suicídio, a ser implementada pela União, em cooperação com os Estados, o Distrito Federal e os Municípios [Internet]. 2019 [cited 2020 Jun 15]. Available from: http://www.in.gov.br/web/dou/-/lei-n\%C2\%BA-13.819-de-26-de-abril-de-2019-85673796

7. Cheung T, Lee PH, Yip PSF. Suicidality among Hong Kong nurses: prevalence and correlates. J Adv Nurs. 2016;72(4):836-848. doi: 10.1111/jan.12869

8. Davidson JE, Proudfoot J, Lee KE, Terterian G, Zisook S. A longitudinal analysis of nurse suicide in the United States (2005-2016) with recommendations for action. Worldviews Evid Based Nurs. 2020;17(1):6-15. doi: 10.1111/wvn.12419

9. Milner AJ, Maheen H, Bismark MM, Spittal MJ. Suicide by health professionals: a retrospective mortality study in Australia, 2001-2012. Med J Aust. 2016;205(6):260-5. doi: 10.5694/mja15.01044

10. Davidson JE, Stuck AR, Zisook S, Proudfoot J. Testing a strategy to identify incidence of nurse suicide in the United States. J Nurs Adm. 2018;48(5):259-65. doi: 10.1097/NNA.0000000000000610

11. Carrasco-Farfan CA, Alvarez-Cutipa D, Vilchez-Cornejo J, Lizana-Medrano M, Durand-Anahua PA, Rengifo-Sanchez JÁ, et al. Alcohol consumption and suicide risk in medical internship: a Peruvian multicentric study. Drug and alcohol review. 2019;38(2):201-208. doi:10.1111/dar.12897

12. Gerada C. Doctors, suicide and mental illness. BJPsych Bull. 2018;42(4):165-168. doi: 10.1192/bjb.2018.11

13. Brooks E, Gendel MH, Early SR, Gundersen DC. When doctors struggle: current stressors and evaluation recommendations for physicians contemplating Suicide. Arch Suicide Res. 2018;22(4):519-28. doi: 10.1080/13811118.2017.1372827 
14. Silva DSD, Tavares NVS, Alexandre ARG, Freitas DA, Brêda MZ, Albuquerque MCS, et al. Depressão e risco de suicídio entre profissionais de Enfermagem: revisão integrativa. Rev Esc Enferm USP. 2015;49(6):1023-31. doi: 10.1590/S0080-623420150000600020

15. Bailey E, Robinson J, McGorry P. Depression and suicide among medical practitioners in Australia. Intern Med J. 2018;48(3):254-8. doi: 10.1111/imj.13717

16. Alderson M, Parent-Rocheleau X, Mishara B. Critical review on suicide among nurses. Crisis. 2015;36(2):91-101. doi: 10.1027/0227-5910/ a000305

17. Santa NS, Cantilino A. Suicídio entre médicos e estudantes de medicina: revisão de literatura. Rev Bras Educ Med. 2016;40(4):772-780. doi: 10.1590/1981-52712015v40n4e00262015

18. Castro SCC, Baroni GV, Martins WA, Palmini ALF, Bisol LW. Suicide risk, temperament traits, and sleep quality in patients with refractory epilepsy. Epilepsy Behav. 2018;80:254-8. doi: 10.1016/j.yebeh.2018.01.022

19. Vasconcelos JRO, Lôbo APS, Melo-Neto VL. Risco de suicídio e comorbidades psiquiátricas no transtorno de ansiedade generalizada. J Bras Psiquiatr. 2015;64(4):259-65. doi: 10.1590/0047-2085000000087

20. Ayhan G, Arnal R, Basurko C, About V, Pastre A, Pinganaud E, et al. Suicide risk among prisoners in French Guiana: prevalence and predictive factors. BMC Psychiatry. 2017;17(1):156. doi: 10.1186/s12888-017-1320-4

21. Sandoval-Ato R, Vilela-Estrada MA, Mejía CR, Alvarado JC. Suicide risk associated with bullying and depression in high school. Rev Chil Pediatr. 2018;89(2):208-15. doi: 10.4067/s0370-41062018000100209

22. Pereira-Morales AJ, Adan A, Camargo A, Forero DA. Substance use and suicide risk in a sample of young Colombian adults: an exploration of psychosocial factors. Am J Addict. 2017;26(4):388-94. doi: 10.1111/ajad.12552

23. Zendron M, Zequi SC, Guimarães GC, Lourenço MTC. Assessment of suicidal behavior and factors associated with a diagnosis of prostate cancer. Clinics. 2018;73:e441. doi: 10.6061/clinics/2018/e441

24. Dutheil F, Pereira B, Dambrun M, Moustafa F, Mermillod M, Baker JS, et al. Suicide among physicians and health-care workers: a systematic review and meta-analysis. PLoS One. 2019;14(12):e0226361. doi: 10.1371/journal.pone.0226361

25. Tomás-Sábado J, Maynegre-Santaulària M, Pérez-Bartolomé M, Alsina-Rodríguez M, Quinta-Barbero R, Granell-Navas S. Síndrome de burnout y riesgo suicida en enfermeras de atención primaria. Enfermería Clínica. 2010;20(3):173-8. doi: 10.1016/j.enfcli.2010.03.004

26. Jiménez-López JL, Arenas-Osuna J, Angeles-Garay U. Síntomas de depresión, ansiedad y riesgo de suicidio en médicos residentes durante un año académico. Rev Med Inst Mex Seguro Soc [Internet]. 2015 [cited 2019 Jun 22];53(1):20-8. Available from: https://www.medigraphic. com/pdfs/imss/im-2015/im151d.pdf

27. Montes-Hidalgo J, Tomás-Sábado J. Autoestima, resiliencia, locus de control y riesgo suicida en estudiantes de enfermería. Enferm Clín. 2016;26(3):188-93. doi: 10.1016/j.enfcli.2016.03.002

28. Von Elm E, Altman DG, Egger M, Pocock SJ, Gøtzsche PC, Vandenbroucke JP. Strengthening the reporting of observational studies in epidemiology (STROBE) statement: guidelines for reporting observational studies. BMJ. 2007;335(7624):806-8 doi: 10.1136/bmj.39335.541782.AD

29. Amorim P. Mini International Neuropsychiatric Interview (MINI): validação de entrevista breve para diagnóstico de transtornos mentais. Rev Bras Psiquiatr. 2000;22(3):106-15. doi: 10.1590/S1516-44462000000300003

30. Marques JMA, Zuardi AW. Validity and applicability of the Mini International Neuropsychiatric Interview administered by family medicine residents in primary health care in Brazil. Gen Hosp Psychiatry. 2008;30(4):303-10. doi: 10.1016/j.genhosppsych.2008.02.001

31. Vignola RCB, Tucci AM. Adaptation and validation of the depression, anxiety and stress scale (DASS) to Brazilian Portuguese. J Affect Disord. 2014;155:104-9. doi: 10.1016/j.jad.2013.10.031

32. Martins BG, Silva WR, Maroco J, Campos JADB. Escala de Depressão, Ansiedade e Estresse: propriedades psicométricas e prevalência das afetividades. J Bras Psiquiatr. 2019;68(1):32-41. doi: 10.1590/0047-2085000000222

33. Pais-Ribeiro JL, Honrado A, Leal I. Contribution to the Adaptation study of the Portuguese Adaptation of the Lovibond and Lovibond Depression Anxiety Stress Scales (EADS) with 21 items. Psicol Saúde Doenças [Internet]. 2004 [cited 2019 May 6];5(2):229-239. Available from: http://www.scielo.mec.pt/pdf/psd/v5n2/v5n2a07.pdf

34. Coutinho LMS, Scazufca M, Menezes PM. Methods for estimating prevalence ratios in cross-sectional studies. Rev Saúde Pública. 2008;42(6):992-8. doi: 10.1590/S0034-89102008000600003

35. Milner A, Witt K, LaMontagne AD, Niedhammer I. Psychosocial job stressors and suicidality: a meta-analysis and systematic review. Occup Environ Med. 2018;75(4):245-53. doi: 10.1136/oemed-2017-104531

36. Carvalho A, Peixoto B, Saraiva CB, Sampaio D, Amaro F, Santos JC, et al. Plano nacional de prevenção do suicídio 2013/2017. Lisboa [Internet]. 2013 [cited 2019 Nov 22]. Available from: https:/www.dgs.pt/documentos-e-publicacoes/plano-nacional-de-prevencao-do-suicido-20132017-pdf.aspx

37. World Health Organization. Preventing suicide: a global imperative. Luxembourg [Internet]. 2014 [cited 2019 Nov 22]. Available from: http:// apps.who.int/iris/bitstream/handle/10665/131056/97892?sequence=1

38. Beutel ME, Klein EM, Brähler E, Reiner I, Jünger C, Michal M, et al. Loneliness in the general population: prevalence, determinants and relations to mental health. BMC Psychiatry. 2017;17(1):97. doi: 10.1186/s12888-017-1262-x

39. Barroso SM, Baptisa MN, Zanon C. Solidão como variável preditora na depressão em adultos. Estud Interdiscip Psicol. 2018;9(3):26-37. doi: 10.5433/2236-6407.2018v9n3suplp26 
40. Karakash S, Solone MMS, Solone M, Shanafelt PM, Chavez J. Methods for estimating prevalence ratios in cross-sectional studies. Clin Obstet Gynecol. 2019;62(3):455-65. doi: 10.1590/S0034-89102008000600003

41. Daily JA. Divorce among physicians and medical trainees. J Am College Cardiol. 2019;73(4):521-4. doi: 10.1016/j.jacc.2018.12.016

42. World Health Organization. Investing in treatment for depression and anxiety leads to fourfold return. Washington [Internet]. 2016 [cited 2019 May 23]. Available from: https://www.who.int/news-room/ detail/13-04-2016-investing-in-treatment-for-depression-and-anxiety-leads-to-fourfold-return

43. Associação Brasileira de Psiquiatria - ABP. Suicídio: informando para prevenir. Comissão de Estudos e Prevenção de Suicídio[Internet]. Brasília. 2014 [cited 2019 Dec 15]. Available from: http://www.flip3d.com.br/web/pub/cfm/index9/?numero=14

44. Montaño SH, Zableh AV, Léon BC, Ospino CG. Riesgo suicida y desesperanza en pacientes psiquiátricos hospitalizados. Pensando Psicol. 2014;10(17):43-51. doi: 10.16925/pe.v10i17.783

45. Rogers ML, Ringer FB, Joiner TE. The association between suicidal ideation and lifetime suicide attempts is strongest at low levels of depression. Psychiatry Res. 2018;270:324-8. doi: 10.1016/j.psychres.2018.09.061

46. Cano-Langreo M, Cicirello-Salas S, López-López A, Aguilar-Vela M. Marco actual del suicidio e ideas suicidas en personal sanitario. Med Segur Trab. 2014;60(234):198-218. doi: 10.4321/S0465-546X2014000100015

47. Neponuceno HJ, Souza BDM, Neves NMBC. Transtornos mentais comuns em estudantes de medicina. Rev Bioét. 2019;27(3):465-70. doi: $10.1590 / 1983-80422019273330$

48. Oliveira RJ, Cunha T. Estresse do profissional de saúde no ambiente de trabalho: causas e consequências. Cad Saúde Desenvolv[Internet]. 2014 [cited 2019 Dec 18];3(2):78-93. Available from: https://www.uninter.com/revistasaude/index.php/cadernosaudedesenvolvimento/ article/download/302/238

49. Chagas D. Riscos psicossociais no trabalho: causas e consequências. Int J Develop Educ Psychol. 2015;2(1):439-46. doi: 10.17060/ ijodaep.2015.n1.v2.24

50. Kovács MJ. Sofrimento da equipe de saúde no contexto hospitalar: cuidando do cuidador profissional [Internet]. Mundo Saúde [Internet]. 2010 [cited 2020 Jun 16];34(4):420-9. Available from: http://www.saocamilo-sp.br/pdf/mundo_saude/79/420.pdf 